
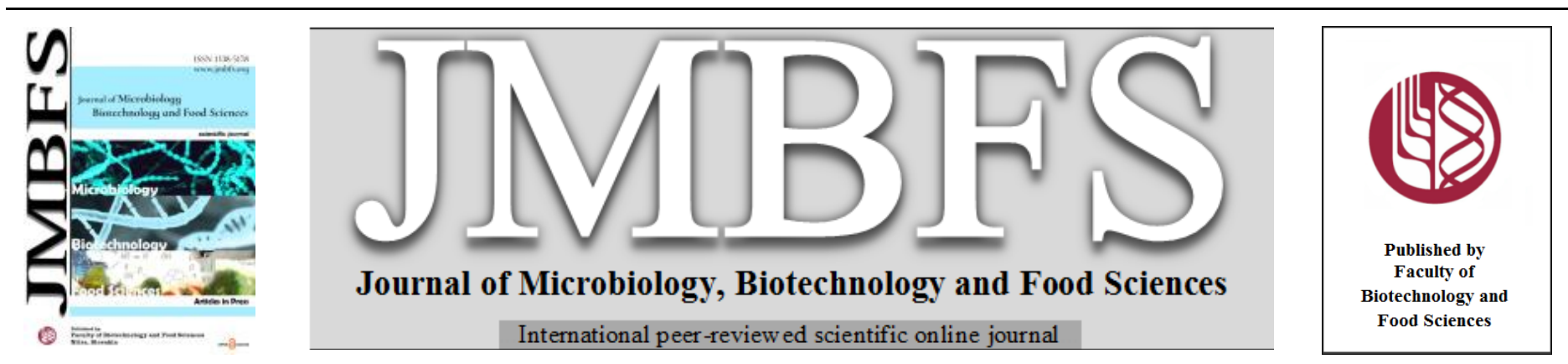

\title{
CONTENT OF BIOGENIC ELEMENTS INDUCTED BY THE INFLUENCE OF THE INOCULANT IN SELECTED CHICKPEA SLOVAK VARIETIES
}

\author{
Erika Zetochová ${ }^{1}$, Alena Vollmannová ${ }^{2}$, Ivana Tirdil'ová ${ }^{3}$
}

\section{Address(es):}

${ }^{1}$ Erika Zetochová, National Agriculture and Food Centre - Research Institute of Plant Production, Bratislavská 122, 92101 Pieštany, Slovak Republic, email:erika.zetochova@nppc.sk

${ }^{2}$ Alena Vollmannová, Slovak University of Agriculture in Nitra, Faculty of Biotechnology and Food Sciences, Department of Chemistry, Tr. A. Hlinku 2, 94976 Nitra, Slovak Republic, e-mail: alena.vollmannova@uniag.sk

${ }^{3}$ Ivana Tirdil’ová, Slovak University of Agriculture in Nitra, AgroBioTech Research Center, Tr. A. Hlinku 2, 94976 Nitra, Slovak Republic, e-mail:

ivana.ika.tirdilova@gmail.com

*Corresponding author: erika.zetochova@nppc.sk

https://doi.org/10.55251/jmbfs.5336

\section{ARTICLE INFO}

Received 28. 9. 2021

Revised 28. 1. 2022

Accepted 28. 1. 2022

Published 1. 6. 2022

\section{Regular article}

OPEN OACCESS

\begin{abstract}
In the study, we focused on the evaluation of the content of biogenic elements inducted by the addition of inoculant in six Slovak chickpea varieties. We analyzed $\mathrm{Cu}, \mathrm{Zn}, \mathrm{Mn}, \mathrm{Fe}, \mathrm{Cr}, \mathrm{Ni}, \mathrm{Co}, \mathrm{K}, \mathrm{Na}, \mathrm{Ca}, \mathrm{Mg}$ and $\mathrm{P}$. We evaluated two variants from each variety control variant (A) and variant with inoculant (B). Seed inoculation was provided by the inoculant Rizobin. We used for analyzed $1 \mathrm{~g}$ from dry seeds from each genotype. We mineralized the samples on a MARS X-press. The result was atomic absorption spectrometry using VARIAN DUO 240FS / $240 \mathrm{Z}$.

The average $\mathrm{Cu}$ content in A control variant was $5.95 \mathrm{mg} . \mathrm{kg}^{-1}$ was reduced to $5.53 \mathrm{mg} . \mathrm{kg}^{-1}$ by the addition of inoculant. For $\mathrm{Zn}$, we also recorded a reduction by the addition of inoculant from $25.43 \mathrm{mg} . \mathrm{kg}^{-1}$ of variant A to $24.95 \mathrm{mg} \cdot \mathrm{kg}^{-1}$ of B variant. The Mn content was the same in both variants and did not change significantly. We recorded the largest differences in the Fe content. The Fe content was reduced from $50.60 \mathrm{mg} . \mathrm{kg}-1$ variant A to $45.07 \mathrm{mg} . \mathrm{kg}-1$ variant $\mathrm{B}$ by adding an inoculant. The content of $\mathrm{Cr}$, Ni and Co did not change significantly with the addition of inoculant. Potassium ranged from $8904.45 \mathrm{mg} . \mathrm{kg}^{-1}$ variant A to $8720 \mathrm{mg} . \mathrm{kg}^{-1} \mathrm{~B}$ variant. Variant A had detected a higher Na content $84.22 \mathrm{mg} . \mathrm{kg}^{-1}$. The average content of $\mathrm{Ca}$ and $\mathrm{Mg}$ was reduced by adding the inoculant of $\mathrm{B}$ variant. The $\mathrm{P}$ content of $1400.88 \mathrm{mg} . \mathrm{kg}-1$ variant B was reduced in variant A to $1346.53 \mathrm{mg} . \mathrm{kg}^{-}{ }^{1}$.
\end{abstract}

Keywords: legumes, chickpea, inoculant, biogenic elements, Slovak varieties

\section{INTRODUCTION}

Chickpeas (Cicer ariatinum L.) is considered one of the oldest legumes and is characterized by high consumption worldwide. It is grown mainly in India, Pakistan, Iran, Ethiopia, Mexico (Raza et al., 2019). It is one of the three most cultivated crops in the world (Ghribi et al., 2015). Cultivation is widespread in more than 50 countries, Asia accounts for $90 \%$ (Kumar, 2019). It is a one-yearold pulp that is suitable for mild to dry climates, has a high heat tolerance, with sufficient soil moisture, prefers a temperate zone (Wallace et al., 2016, Bulbula, 2018).

We distinguish two types of chickpeas: Kabuli and Desi. The Kabuli type is grown in the Mediterranean. These are large seeds $(100-750 \mathrm{mg})$, which are typical of a round shape, have a smooth beige surface and are grown in America. Their energy value is approximately $365 \mathrm{kcal} / 100 \mathrm{~g}$ (Bulbula, 2018). Desi is grown mainly in semi-arid terrains, forming small $(80-350 \mathrm{mg})$, charred seeds that have a rough and grooved surface. They are dark colored and have an energy value of $327 \mathrm{kcal} / 100$ $\mathrm{g}$ (Rachwat et al., 2015). Chickpeas are one of the main growing commodities among field crops (Kumar, 2019). It plays an important role in maintaining soil fertility due to biological nitrogen fixation (Cherinet and Tazebachew, 2016).

An important characteristic of legumes, where we also recommend chickpeas, is their specific property, the ability to bind atmospheric nitrogen and thus form a symbiosis of soil bacteria and rhizobia. The rhizobium consists of several families and genera (Peix, 2015).

Nodes in the roots or stems of legumes are induced by bacteria, followed by nitrogen fixation after the infection process (Peix et al., 2010). Due to this biological fixation by rhizobial strains, we could consider chickpeas to be an excellent crop and catch crop that improves soil fertility and structure. In addition, it reduces soil erosion within the agricultural production system (Shurigin et al. 2015).

Inoculation of legumes with rhizobia causes metabolic changes in plants, the most studied of which are increases in nitrogen and protein content, and which have benefited in agriculture and improve the yield of many legumes (Morel et al., 2012).In recent years, the increased content of plant elements other than phosphorus has been studied after inoculation with phosphate-solubilizing rhizobia (Dahale et al., 2016) and at the same time the increase in potassium using Ksolubilizing bacteria is currently being analyzed. (Kumar et al., 2016) Rhizobial inoculation not only increases yields, it also improves product quality by increasing the content

protein, crude fiber, fat, ash and carbohydrates in chickpeas (Aslam et al., 2010, Abdalla et al., 2013 and Singh et al., 2014).

According to Togaya et al. (2008) the rhizobia inoculation caused the increased plant height, first teat height, number of branches, number of teats per plant, number of seeds per plant and grain yield. Many studies on a global scale have shown a positive effect of rhizobia inoculation on chickpea nodulation, growth and yield (Rehan et al., 2018), which are associated with a broad root system, increased nutrient recovery (Yadav and Verma, 2014). Inoculation affects the growth and development of photosynthesis organs and the level of assimilation (Moinuddin et al., 2014), along with the synthesis of various phytohormones such as indoleacetic acid (IAA) (Verma et al., 2013).

According to Aslam et al. (2000) inoculation of chickpeas with rhizobium strains affects the number of nodules as well as the fresh weight of the root compared to uninoculated plants. We rank legume among the crops that are part of the human diet, as they are

a good and cheap source of protein, fat, carbohydrates and fiber (Bark, 1996; Embaby 2000). The minerals that chickpea plants obtain from the soil environment are arriving into seeds. (Della Penna, 1999). Chickpea seeds are thus a source of several essential minerals for humans. Content of Biogenic elements varies depending on chickpea genotype and growing conditions. (Abebe et al., 200.6)

Chickpeas are characterized by protein content (18-29\%) with its high digestibility (53-89\%), contains carbohydrates (59-65\%), fiber (3-17\%), lipids (4.5-6.6\%) and ash (2.48-3.50\%). Compared to other legumes, it is one of the foods that lowers 
cholesterol (Raza et al., 2019). We rank chickpeas in terms of nutrition as an excellent source of macronutrients, they contain minerals (phosphorus, calcium, magnesium, iron, zinc, potassium, sodium, copper and manganese) and vitamins (vitamin $\mathrm{C}$, thiamine, riboflavin, niacin, pantothenic acid, folate, vitamin B6, choline, vitamin $\mathrm{K}$, vitamin $\mathrm{E}$ and vitamin A) and $\beta$-carotene (Hoskem et al., 2017)

Copper, chromium, iron and zinc are essential micronutrients for human health. They play an important role in human metabolism and their interest is increasing in the context of information on the relationship between trace element status and oxidative diseases (Pelus et al., 1994; Fennema, 2000).

Zinc deficiency has also come to the attention of nutritionists, economists and medical scientists. Micronutrient malnutrition appears to be a serious global threat, affecting more than $33 \%$ of the world's population (WHO 2012). The global zinc deficiency affects about 1.1 billion people, where pregnant women and children are most at risk. Zinc deficiency results in health disorders such as immune system abnormalities, impaired physical growth and learning, and an increased risk of infections (Gibson 2006; Prasad 2007).

Magnesium, which is an important part of the basic processes of energy production and nucleic acid synthesis, is part of more than 300 enzyme systems (Saris et al. 2000). It is also involved in the regulation of muscle contraction (including cardiac), blood pressure and insulin metabolism, as well as in the synthesis of DNA, RNA and proteins (Gröber et al., 2015).

Sodium is a very important mineral for human health. It maintains the volume of plasma, regulates the water content in the body and ensures the balance of electrolytes. In addition, it is responsible for nerve impulse transmission and normal cell function. Increased sodium in a person's diet can cause high blood pressure. This problem is usually associated with high consumption of sugar and fat, in addition to salt (Elias et al., 2020).

Phosphorus is a basic element of hydroxyapatite, a key inorganic component of bone. It is also essential for many cellular compounds, such as phospholipids, phosphoproteins, nucleic acids, and adenosine triphosphate (ATP) (Arnaud and Sanchez, 1996)

Lipids (4-10\%) are also present in small concentrations in chickpeas, unsaturated fatty acids are also represented, especially linoleic $(54.7-56.2 \%)$, oleic (21.6$22.2 \%)$, linolenic $(0.5-0.9 \%)$ ), palmitic $(18.9-20.4 \%)$ and stearic $(1.3-1.7 \%)$ (Rachwat et al., 2015). In addition, alkaloids, lectins, saponins, phytic acid and trypsin, chymotrypsin and $\alpha$-amylases are present. (Rachwat $\boldsymbol{e t}$ al., 2015, Chen $\boldsymbol{e}$ al., 2014). Finally, chickpeas contain phytochemicals such as phenols, which represent 0.72 to $1.81 \mathrm{mg} / \mathrm{g}$ of seed (Rachwat et al., 2015). The study was aimed on content of biogenic elements which were inducted by the influence of inoculant on the content of biogenic elements in selected chickpea Slovak varieties.

\section{MATERIAL AND METHODS}

\section{Material for analysis}

The plant material for analyses was sown on the field trials plots it the National Agricultural and Food Center - Research Institute of Plan Production in Pieštany (GPS coordinates 48.5917973 and 7.827155). Due to their location, the climatic conditions of Pieštany are very favourable. Pieštany is one of the warmest areas in Slovakia. Their climate is typically lowland, slightly dry, but also slightly windy. The average annual air temperature is $9.4^{\circ} \mathrm{C}$. The annual average precipitation is $611 \mathrm{~mm}$. Due to favourable climatic conditions and soil fertility was in the past this area considered a major agricultural regions of Slovakia. In our work we analysed 6 selected genotypes of chickpea (Cicer arietinum L.) (Table 1). Al selected genotypes are of Slovak origin and were provided for this study by the Gene Bank of the Slovak Republic.

Two variants were seeded from each genotype, a control variant (A) and a inoculant variant (B). The size of individual plots for a plant material was $5.2 \times 1.5$ $\mathrm{m}$. Seed inoculation was provided by the inoculant Rizobin, which is used to inoculate legume seeds. It is manufactured in England (Legume technology Ltd). It has a high content of live bacteria $(5 * 109)$. An organic polymer was used as a binder in the preparation. Rizobin was mixed to the seeds by manual application at a dose of $350 \mathrm{~g}$. ha- 1 . We evaluated the content of biogenic elements from measured values in 2019. Samples of selected genotypes of chickpea were taken at full maturity, dried and subsequently purified. Each analysis was done using $1 \mathrm{~g}$ of average sample in four repetitions.

Table 1 Chickpea (Cicer arietinum L.) accession analysed.

\begin{tabular}{lc}
\hline Chickpea / Genotypes & Origin \\
\hline Krajova z Kralovej & SVK \\
Maskovsky Bagovec & SVK \\
Businsky & SVK \\
Slovak & SVK \\
Beta & SVK \\
Alfa & SVK \\
\hline
\end{tabular}


Legumes generally have a high iron and mineral content (Sundberg, 2002). Fe concentrations in chickpeas have been found to range from 3 to $14.3 \mathrm{ppm}$ (Wood and Grusak, 2007), but due to the presence of naturally occurring inhibitors, only a small amount is bioavailable (Hemalatha et al., 2007). In our samples the iron content ranged from $44.50 \mathrm{mg} . \mathrm{kg}^{-1}$ (Beta) to $58.90 \mathrm{mg} . \mathrm{kg}^{-1}$ (Businsky) in A variant Due to the addition of the inoculant, all varieties had a reduced $\mathrm{Fe}$ about content of $1.80 \%$ to $21.22 \%$ (Table 2.3). Statistical comparison of the Fe content in A and B variants we found, that since the P-value is less than 0,05 in all tests, there is a statistically significant difference between the averages of these two samples at the 95.0\% confidence level (Table 4 ). The obtained parameters of our analysis are comparable with Wang and Daun (2004), who reported a range of 2.50-5.20, $0.40-0.90$ and $4.30-7.90 \mathrm{mg} / 100 \mathrm{~g}$ for $\mathrm{Zn}, \mathrm{Cu}$, and $\mathrm{Fe}$, respectively.

The Beta variety had the same chromium content in both variants of $0.70 \mathrm{mg} \cdot \mathrm{kg}^{-1}$. In variant A, the chromium content ranged from 0.40 mg.kg-1 (Krajova z Kralovej, Maskovsky Bagovec) to $0.80 \mathrm{mg} \cdot \mathrm{kg}^{-1}$ (Businsky). The chromium content was increased by $50 \%$ by adding an inoculant in the Maskovsky Bagovec variety (Table $2,3)$. By statistical evaluation of the $\mathrm{Cr}$ content in $\mathrm{A}$ and $\mathrm{B}$ variants based on the comparison of two samples using t-test, W-test, F-test and K-S test, there is no statistically significant difference between the averages of these two samples at the level of $95.0 \%$ onfidence level (Table 4 ).

The nickel content was from $0.50 \mathrm{mg} \cdot \mathrm{kg}^{-1}$ (Krajova z Kralovej, Maskovsky Bagovec) to $1.00 \mathrm{mg} \cdot \mathrm{kg}^{-1}$ (Businsky). The nickel content was reduced by $50 \%$ (Beta) by the inoculant addition in B variant. In other varieties, the nickel content was increased by the addition of an inoculant.

Krajova z Kralovej and Businsky had the same cobalt content in both variants 0.40 $\mathrm{mg} \cdot \mathrm{kg}^{-1}$. The increased cobalt content in all monitored varieties (Table 2.3) was recorded by the addition of inoculant.
Table 2 Average values of microelement content in selected chickpea (Cicer arietinum L.) genotypes in control A variant.

\begin{tabular}{lccccccc}
\hline \multirow{2}{*}{ Crop } & \multicolumn{6}{c}{$\begin{array}{c}\text { Content of selected microelements in chickpea } \\
\text { Cicer arietinum }\end{array}$ L. $)$ in control A variant $/ \mathbf{m g}^{-1}$} \\
\hline Chickpea varieties & Cu & Zn & Mn & Fe & Cr & Ni & Co \\
Krajova z Kralovej & 5.90 & 25.10 & 19.70 & 51.60 & 0.40 & 0.50 & 0.40 \\
Maskovsky Bagovec & 6.10 & 25.00 & 19.10 & 51.80 & 0.40 & 0.50 & 0.20 \\
Businsky & 6.60 & 26.20 & 21.10 & 58.90 & 0.80 & 1.00 & 0.40 \\
Slovak & 5.40 & 25.90 & 19.40 & 51.10 & 0.60 & 0.80 & 0.30 \\
Beta & 5.90 & 24.70 & 17.10 & 44.50 & 0.70 & 0.80 & 0.20 \\
Alfa & 5.80 & 25.70 & 19.70 & 45.70 & 0.70 & 0.60 & 0.40 \\
\hline
\end{tabular}

Table 3 Measured average values of microelement content in selected chickpea (Cicer arietinum L.) genotypes in variant with addition inoculant B

\begin{tabular}{lcccccccc}
\hline Crop & \multicolumn{7}{c}{$\begin{array}{c}\text { Content of selected microelements in chickpea } \\
\text { (Cicer arietinum }\end{array}$} & L.) in B variant \\
\hline Chick.kg-1 & Bnea varieties & Cu & Zn & Mn & Fe & Cr & Ni & Co \\
Krajova z Kralovej & 5.20 & 23.80 & 18.70 & 44.10 & 0.50 & 0.80 & 0.40 \\
Maskovsky Bagovec & 5.80 & 24.90 & 20.60 & 45.20 & 0.60 & 0.90 & 0.30 \\
Businsky & 5.90 & 25.50 & 19.70 & 46.40 & 0.70 & 1.20 & 0.40 \\
Slovak & 5.50 & 26.80 & 18.50 & 48.80 & 0.40 & 1.00 & 0.40 \\
Beta & 4.80 & 22.40 & 17.40 & 43.70 & 0.70 & 0.40 & 0.30 \\
Alfa & 6.00 & 26.30 & 21.00 & 42.20 & 0.80 & 1.00 & 0.70 \\
\hline
\end{tabular}

Table 4 Measured values of microelement content in selected chickpea (Cicer arietinum L.) varieties in the monitored variants A and B with P-values derived from t-test, F-test, W-test and K-S Test.

\begin{tabular}{|c|c|c|c|c|c|c|}
\hline Element & $\begin{array}{c}\text { Chickpea } \mathrm{A} \\
\text { (average } \pm \text { SD) }\end{array}$ & $\begin{array}{c}\text { Chickpea B } \\
\text { (average } \pm \text { SD) }\end{array}$ & $\begin{array}{c}\mathbf{t}^{1} \text {-test } \\
\text { (P-value) }\end{array}$ & $\begin{array}{c}\mathbf{F}^{2} \text {-test } \\
\text { (P-value) }\end{array}$ & $\begin{array}{l}\mathrm{W}^{3} \text {-test } \\
\text { (P-value) }\end{array}$ & $\begin{array}{l}\text { K-S }{ }^{4} \text {-test } \\
\text { (P-value) }\end{array}$ \\
\hline $\mathbf{C u}$ & $5.950 \pm 0.394$ & $5.533 \pm 0.463$ & 0.001 & 0.469 & 0.004 & 0.031 \\
\hline $\mathbf{Z n}$ & $25.433 \pm 0.585$ & $24.95 \pm 1.636$ & 0.189 & 0.012 & 0.397 & 0.259 \\
\hline Mn & $19.350 \pm 1.229$ & $18.630 \pm 3.313$ & 0.381 & 0.000 & 0.649 & 0.259 \\
\hline $\mathbf{F e}$ & $50.600 \pm 5.154$ & $45.067 \pm 2.166$ & 0.000 & 0.000 & 0.000 & 0.000 \\
\hline $\mathrm{Cr}$ & $0.6001 \pm 0.167$ & $0.616 \pm 0.147$ & 0.719 & 0.502 & 0.812 & 0.893 \\
\hline $\mathbf{N i}$ & $0.700 \pm 0.200$ & $0.884 \pm 0.271$ & 0.009 & 0.320 & 0.005 & 0.005 \\
\hline Co & $0.333 \pm 0.098$ & $0.418 \pm 0.147$ & 0.014 & 0.009 & 0.057 & 0.259 \\
\hline
\end{tabular}

${ }^{1}$ t-test to compare means; ${ }^{2}$ F-test to compare standard deviations; ${ }^{3}$ Mann-Whitney (Wilcoxon) W-test to compare medians; ${ }^{4}$ Kolmogorov-

Smirnov test to compare the distributions of the two samples.

Minerals from the soil environment are transported to chickpea plants and get into the seeds (Grusak a DellaPenna, 1999). The main minerals that a plant provides to humans (e.g., Na, I, Se and Cr), may not be important to plants. Many of these essential minerals provide chickpea seeds to humans. From macro elements we focused in our experiment on content of $\mathrm{K}, \mathrm{Na}, \mathrm{Ca}, \mathrm{Mg}$ and $\mathrm{P}$ in selected varieties of chickpea (Graph 2.) in control A variant and variant with inoculant B.

\section{Content of macroelements in selected genotypes of chickpea in mg.k $\bar{g}^{1}$}

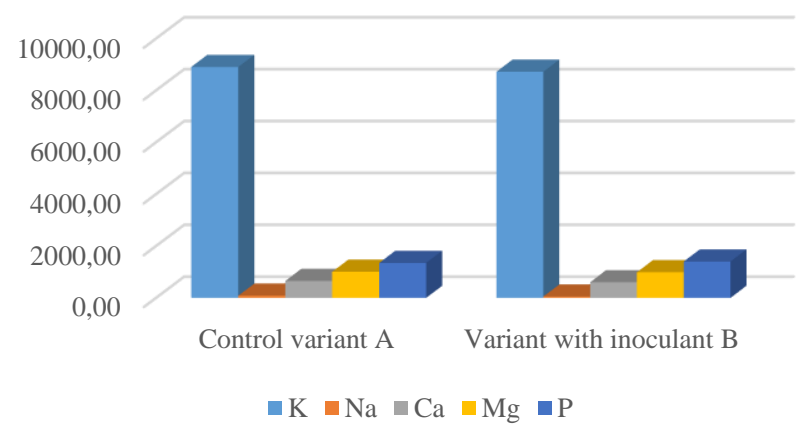

Graf 2 Comparison of average values of macroelement content in selected chickpea (Cicer arietinum L.) genotypes in both variants A and B in $\mathrm{mg} . \mathrm{kg}^{-1}$.

The major and most abundant cation in the intracellular fluid is potassium. It plays an important role in maintaining cell function. Its value determines through the cell membrane the potential of the cell membrane, which is ensured by the ubiquitous ion channel $\mathrm{Na}-\mathrm{K}(\mathrm{Na}+-\mathrm{K}+)$ ATPase pump (Stone et al., 2016). Potassium content varied from $8198.70 \mathrm{mg} . \mathrm{kg}-1$ (Slovak) to $9221.20 \mathrm{mg} . \mathrm{kg}-1$ (Alfa) in control A variant. The addition of inoculant in B variant reduced the content of potassium in all varieties except Beta, where the content of potassium was $0.45 \%$ higher.

Another evaluated element was calcium. The most common element in the body is calcium, which is very important and necessary for many functions in the human body. Up to $99 \%$ of $\mathrm{Ca}$ occurs in bones and teeth. Ca metabolism also contains proteins, vitamin D and $\mathrm{P}$ (Beto, 2015). Calcium is most contained in seed cover. In the case of Ca deficiency, it would be appropriate to consume whole chickpea seeds (Abebe et al., 2006). Özcana et al. (2013) report Ca values of $1.309 \mathrm{mg} . \mathrm{kg}$ -1 (C. arietinum L.) The content of calcium in control A variant ranged from $559.60 \mathrm{mg} \cdot \mathrm{kg}^{-1}$ (Beta) to $773.80 \mathrm{mg} \cdot \mathrm{kg}^{-1}$ (Slovak). In variety Slovak, the Ca content decreased by $26.10 \%$ due to the inoculant.

Of the macrorelements, chickpeas are a rich source of phosphorus and magnesium. The lowest magnesium content was found in the variety Krajova z Kralovej 949.10 mg.kg-1, the highest in the variety Slovak 1061.00 mg. $\mathrm{kg}^{-1}$ in control A variant. The addition of inoculant reduced the magnesium content in all varieties from $0.60 \%$ (Beta) to $12.58 \%$ (Slovak). A statistically significant difference between chickpea A and chickpea B was proven for potassium (W-test, K-test), magnesium (W-test), and calcium (t-test, W-test) $\mathrm{P}<0,05$.

The lowest sodium content in the Alfa variety was $68.80 \mathrm{mg} \cdot \mathrm{kg}^{-1}$, the highest in the Maskovsky Bagovec variety was $103.20 \mathrm{mg} \cdot \mathrm{kg}^{-1}$ in control A variant. The effect of inoculant in B variant reduced the sodium content in all varieties monitored.

The last element monitored was phosphorus. Its content in control A variant ranged from $1155.10 \mathrm{mg} \cdot \mathrm{kg}^{-1}$ (Slovak) to $1522.10 \mathrm{mg} \cdot \mathrm{kg}^{-1}$ (Maskovsky Bagovec). Addition of inoculant increased the content by $16.33 \%$ (Businsky). It has an important position in human structure and metabolism. By statistical evaluation of 
the $\mathrm{P}$ content in $\mathrm{A}$ and $\mathrm{B}$ variants based on the comparison of two samples using $\mathrm{t}$ test, W-test, F-test and K-S test, there is no statistically significant difference between the averages of these two samples at the level of $95.0 \%$. confidence level (Table 5).

Table 5 Measured values of monitored macro-elements in selected chickpea (Cicer arietinum L.) varieties in the monitored variants A and B with P-values derived from t-test, F-test, W-test and K-S Test.

\begin{tabular}{lcccccc}
\hline Element & $\begin{array}{c}\text { Chickpea A } \\
\text { (average } \pm \text { SD) }\end{array}$ & $\begin{array}{c}\text { Chickpea B } \\
\text { (average } \pm \text { SD) }\end{array}$ & $\begin{array}{c}\text { t-test } \\
\text { (P-value) }\end{array}$ & $\begin{array}{c}\text { F-test } \\
\text { (P-value) }\end{array}$ & \multicolumn{2}{c}{ W-test } \\
(P-value) & K-S test \\
K & $8904.450 \pm 341.971$ & $8720.00 \pm 308.144$ & 0.0557 & 0.621 & 0.003 \\
Na & $84.216 \pm 12.025$ & $50.217 \pm 9.125$ & 0.000 & 0.193 & 0.000 \\
Ca & $651.233 \pm 77.962$ & $601.883 \pm 58.499$ & 0.017 & 0.176 & 0.021 \\
Mg & $1007.180 \pm 43.059$ & $990.400 \pm 46.643$ & 0.202 & 0.704 & 0.049 \\
P & $1346.530 \pm 135.657$ & $1400.880 \pm 171.465$ & 0.229 & 0.268 & 0.139 & 0.139 \\
\hline
\end{tabular}

${ }^{1}$ t-test to compare means; ${ }^{2}$ F-test to compare standard deviations; ${ }^{3}$ Mann-Whitney (Wilcoxon) W-test to compare medians; ${ }^{4}$ KolmogorovSmirnov test to compare the distributions of the two samples.

\section{CONCLUSION}

In our study, we focused on the effect of inoculation on the content of biogenic elements in the seeds of selected Slovak chickpea genotypes. We evaluated $\mathrm{Cu}$ $\mathrm{Zn}, \mathrm{Mn}, \mathrm{Fe}, \mathrm{Cr}, \mathrm{Ni}$ and $\mathrm{Co}$ from micro elements and $\mathrm{K}, \mathrm{Na}, \mathrm{Ca}, \mathrm{Mg}$ and $\mathrm{P}$ from macro elements. Kaya et.al., (2018) are reported the content of macro elements $\mathrm{K}$ from 9811 to $14370 \mathrm{ppm}$, Ca from 886 to 3008 ppm, Mg form 1218 to 2037ppm, $\mathrm{Na}$ from 10to 507ppm and P from 3109 to $5503 \mathrm{ppm}$ in the selected Turkey chickpea without influence of inoculant. Soil suitability of individual cultivars, soil conditions, fertilization, irrigation and weather etc. are among the factors affecting the elemental contents of plants (Kan et $\boldsymbol{a l . , 2 0 0 5}$ ). According to Zia-Ul-Haq et al. (2012) in the evaluated legumes of Pakistan (Desi chickpeas, Kabuli chickpeas, lentils, mung beans, mashed beans and peas), were detectable amounts of 15 to 31 g.kg-1 Na, 189 to 210 g.kg-1 Ca, 152 to 166 g .kg-1 P, 169 to 196 g.kg-1 K, 135 to $167 \mathrm{~g} . \mathrm{kg}-1 \mathrm{Mg}, 6$ to $10 \mathrm{mg} . \mathrm{kg}-1 \mathrm{Fe}, 11$ to $17 \mathrm{mg} . \mathrm{kg}-1 \mathrm{Cu}$ and 24 to $39 \mathrm{mg}$.kg$1 \mathrm{Zn}$. According to literature sources, some differences in mineral content have been demonstrated. The differences found can be influenced by different legumes, the location, the harvest period and the nutritional status of the plants and many other factors that affect the mineral content.

We found that inoculation did not significantly affect the contents of individua elements. A statistically significant difference was reflected in the content of Fe on the comparison of two samples using t-test, W-test, F-test and K-S test. Conversely, statistical evaluation of the $\mathrm{P}$ content in variants $\mathrm{A}$ and $\mathrm{B}$ based on the comparison of two samples using t-test, W-test, F-test and KS test is not a statistically significant difference between the averages of these two samples. at a confidence level of $95.0 \%$. Statistical evaluation of the $\mathrm{Cr}$ content in variants A and $\mathrm{B}$ based on the comparison of two samples using t-test, W-test, F-test and KS test, we found that there is no demonstrable difference between the averages of these two samples at the level of $95.0 \%$. level of confidence.

Acknowledgments: This publication was supported by the grants VEGA 1/0113/21 financed by The Ministry of Education, Science, Research and Sport of the Slovak Republic.

This publication was supported by the Operational Program Integrated Infrastructure within the project: Demand-driven research for the sustainable and innovative food, Drive4SIFood 313011V336, cofinanced by the European Regional Development Fund.

\section{REFERENCES}

Abdalla, A. S., Abdelgani, M. E., \& Osman, A. G. (2013). Effects of biological and mineral fertilization on yield, chemical composition and physical characteristics of chickpea (Cicer arietinum L.) seeds. Pakistan Journal of Nutrition, 12(1), 1. DOI: 10.3923/pjn.2013.1.7

Alem, C., \& Asres, T. (2016). 12. Participatory evaluation and selection of chickpea varieties at Debre Mawi and Debre Yakob watersheds, Western Amhara Region, Ethiopia. Harnessing Chickpea Value Chain for Nutrition Security and Commercialization of Smallholder Agriculture in Africa, 163.

Arnaud, C.D. and Sanchez, S.D. (1996) Calcium and phosphorus. In: Ziegler, E.E. and Filer, L.J. Jr (eds) Present Knowledge in Nutrition, 7th edn. International Life Sciences Institute, Washington, DC, pp. 245-255

Bakr, A.A., (1996) Effect of Egyptian cooking methods of faba beans on its nutritive values, dietary protein utilization and iron deficiency anemia. 1 . The role of main technological pretreatments. Plant Foods Hum Nutr 49(1):83-92 2 https://doi.org/10.1007/BF01092525

Beto, J.A., "The role of calcium in human aging," Clinical Nutrition Research, vol. 4, no. 1, pp. 1-8, 2015

Bulbula, D.D. - Urga, K. 2018. Study on the effect of traditional processing methods on nutritional composition and antinutritional factors in chickpea (cicer arietinum). Cogent Food \& Agriculture, 2018, 4.1: 1422370 DOI:10.1080/23311932.2017.1422370

Dahale, S. K., Prashanthi, S. K., \& Krishnaraj, P. U. (2016). Rhizobium mutant deficient in mineral phosphate solubilization activity shows reduced nodulation and plant growth in green gram. Proceedings of the National Academy of Sciences, India Section B: Biological Sciences, 86(3), 723-734. https://doi.org/10.1007/s40011-015-0500-6

DellaPenna, D., \& Pogson, B. J. (2006). Vitamin synthesis in plants: tocopherols and carotenoids. Annu. Rev. Plant Biol., 57, 711-738 https://doi.org/10.1146/annurev.arplant.56.032604.144301

Elias, M., Laranjo, M., Agulheiro-Santos, A. C., \& Potes, M. E. (2020). The role of salt on food and human health. Salt in the Earth, 19 https://dx.doi.org/10.5772/intechopen.86905

Embaby, H., (2000) Antinutritional factors in some Egyptian cereals and legumes, M.Sc. Thesis, Food Technology Department Faculty of Agriculture, Suez Canal University, Ismailia, Egypt

Gibson, R. S. (2006). Zinc: the missing link in combating micronutrient malnutrition in developing countries. Proceedings of the Nutrition Society, 65(1), 51-60.doi:10.1079/PNS200547

Ghribi, A., Maklouf, I., Blecker, C., Attia, H., \& Besbes, S. (2015). Nutritional and com-positional study of desi and kabuli chickpea (Cicer arietinum L.) flours from Tunisian cultivars. Adv Food Technol Nutr Sci Open J, 1(2), 38-47. https://dx.doi.org/10.17140/AFTNSOJ-1-107

Gröber, U., Schmidt, J., \& Kisters, K. (2015). Magnesium in prevention and therapy. Nutrients, 7(9), 8199-8226. https://doi.org/10.3390/nu7095388

Grusak, M. A., \& DellaPenna, D. (1999). Improving the nutrient composition of plants to enhance human nutrition and health. Annual review of plant biology, 50(1), 133-161. https://doi.org/10.1146/annurev.arplant.50.1.133

Hemalatha, S., Platel, K., \& Srinivasan, K. (2007). Zinc and iron contents and their bioaccessibility in cereals and pulses consumed in India. Food Chemistry, 102(4) 1328-1336. https://doi: 10.1016/j.foodchem.2006.07.015

Hoskem, B. C. S., da Costa, C. A., Nascimento, W. M., Santos, L. D. T., Mendes, R. B., \& de Campos Menezes, J. B. (2017). Productivity and quality of chickpea seeds in Northern Minas Gerais, Brazil. Revista Brasileira de Ciências Agrárias, 12(3), 261-268. https://doi.org/10.5039/agraria.v12i3a5445

Hotz, C., \& Brown, K. H. (2004). Assessment of the risk of zinc deficiency in populations and options for its control...

Chen, H., Ma, H. R., Gao, Y. H., Zhang, X., Habasi, M., Hu, R., \& Aisa, H. A. (2015). Isoflavones extracted from chickpea Cicer arietinum L. sprouts induce mitochondria-dependent apoptosis in human breast cancer cells. Phytotherapy Research, 29(2), 210-219. https://doi.org/10.1002/ptr.5241

Kan, Y., Kan, A., Ceyhan, T., Sayar, E., Kartal, M., Altun, L., ... \& Cevheroğlu, S. (2005). Atomic absorption spectrometric analysis of Trigonella foenum-graecum L. seeds cultivated in Turkey. Turkish J. Pharm. Sci, 2(3), 187-191.

Kaya, M., Kan, A., Yilmaz, A., Karaman, R., \& Sener, A. (2018). The fatty acid and mineral compositions of different chickpea cultivars cultivated. Fresenius Environmental Bulletin, 27(2), 1240-1247.

Kumar, A., \& Meena, V. S. (2019). Plant Growth Promoting Rhizobacteria for Agricultural Sustainability. Berlin: Springer, doi, 10, 978-981.

Kumar, P. A. N. K. A. J., Dubey, R. C., Maheshwari, D. K., \& Bajpai, V. (2016) ACC deaminase producing Rhizobium leguminosarum rpn5 isolated from roo nodules of Phaseolus vulgaris L. Bangladesh J Bot, 45, 477-484.

Li, L., \& Yang, X. (2018). The essential element manganese, oxidative stress, and metabolic diseases: links and interactions. Oxidative medicine and cellular longevity, 2018. https://doi.org/10.1155/2018/7580707

Moinuddin, D. T., Hussain, S., Khan, M. M. A., Hashmi, N., Idrees, M., Naeem, M., \& Ali, A. (2014). Use of $\mathrm{N}$ and $\mathrm{P}$ biofertilizers together with phosphorus fertilizer Improves growth and physiological attributes of chickpea. Global Journal of Agriculture and Agricultural Sciences, 2(3), 168-174. 
Morel, M. A., Braña, V., \& Castro-Sowinski, S. (2012). Legume crops, importance and use of bacterial inoculation to increase production. Crop plant, 12, 218-240.

Muhammad, A., Ahmad, H. K., Muhammad, A., Ejaz, A., Sagoo, A. G., Inayat, U., ... \& Muhammad, M. (2010). Nodulation, grain yield and grain protein contents as affected by rhizobium inoculation and fertilizer placement in chickpea cultivar bittle-98. Sarhad Journal of Agriculture, 26(4), 467-474.

Özcan, M. M., Dursun, N., \& Juhaimi, F. A. (2013). Macro-and microelement contents of some legume seeds. Environmental monitoring and assessment, 185(11), 9295-9298. https://doi.org/10.1007/s10661-013-3252-x

Peix, A., et al. Bacterial associations with legumes. Critical Reviews in Plant Sciences, 2015, 34.1-3: 17-42.

Peix, A., Velázquez, E., Silva, L. R., \& Mateos, P. F. (2010). Key molecules involved in beneficial infection process in rhizobia-legume symbiosis In Microbes for legume improvement (pp. 55-80). Springer, Vienna. https://doi.org/10.1007/978-3-211-99753-6_3

Pelus, E., Arnaud, J., Ducros, V., Faure, H., Favier, A., \& Roussel, A. M. (1994). Trace element $(\mathrm{Cu}, \mathrm{Zn}, \mathrm{Fe}, \mathrm{Mn}, \mathrm{Se})$ intakes of a group of French men using the duplicate diet technique. International journal of food sciences and nutrition, 45(1), 63-70. https://doi.org/10.3109/09637489409167018

Prasad, A. S. (2007). Zinc: mechanisms of host defense. The Journal of nutrition, 137(5), 1345-1349. https://doi:10.1093/jn/137.5.1345

Rachwa-Rosiak, D., Nebesny, E., \& Budryn, G. (2015). Chickpeas-composition, nutritional value, health benefits, application to bread and snacks: a review. Critical Reviews in Food Science and Nutrition, 55(8), 11371145. https://doi.org/10.1080/10408398.2012.687418

Raza, H., Zaaboul, F., Shoaib, M., \& Zhang, L. (2019). An overview of physicochemical composition and methods used for chickpeas processing. International Journal of Agriculture Innovations and Research, 7(5), 495-500.

Rehan, W., Jan, A., Liaqat, W., Jan, M. F., Ahmadzai, M. D., Ahmad, H., ... \& Ali, N. (2018). 5. Effect of phosphorous, rhizobium inoculation and residue types on chickpea productivity. Pure and Applied Biology (PAB), 7(4), 1203-1213. http://dx.doi.org/10.19045/bspab.2018.700140

Salunkhe, D. K., \& Kadam, S. S. (1989). CRC handbook of world food legumes: nutritional chemistry, processing technology, and utilization

Sandberg, A. S. (2002). Bioavailability of minerals in legumes. British Journal of Nutrition, 88(S3), 281-285. http://doi: 10,1079/BJN/2002718

Saris, N. E. L., Mervaala, E., Karppanen, H., Khawaja, J. A., \& Lewenstam, A. (2000). Magnesium: an update on physiological, clinical and analytical aspects. Clinica chimica acta, 294(1-2), 1-26. doi: 10.1016/S00098981(99)00258-2.

Shurigin, V., Davranov, K., Abdiev, A., 2015. Screening of salt tolerant rhizobia for improving growth and nodulation of chickpea (Cicer arietinum) under arid soil conditions of Uzbekistan. Journal of Biological and Chemical Research. 32 (2): 534-540.

Singh, H., P. Singh, R.P. Singh and M. Tripathi. 2014. Biochemical and molecular studies on rhizobium inoculated chickpea (Cicer arietinum L.) genotype grown in Eastern UP. American Journal of Biochemistry and Molecular Biology. http://DOI 0.3923/ajbmb.2014

Stone, M. S., Martyn, L., \& Weaver, C. M. (2016). Potassium intake, bioavailability, hypertension, and glucose control. Nutrients, 8(7), 444. https://doi.org/10.3390/nu8070444

Togay, N., Togay, Y., Cimrin, K. M., \& Turan, M. (2008). Effects of Rhizobium inoculation, sulfur and phosphorus applications on yield, yield components and nutrient uptakes in chickpea (Cicer arietinum L.). African Journal of Biotechnology, 7(6).

Verma, J. P., Yadav, J., Tiwari, K. N., \& Kumar, A. (2013). Effect of indigenous Mesorhizobium spp. and plant growth promoting rhizobacteria on yields and nutrients uptake of chickpea (Cicer arietinum L.) under sustainable agriculture. Ecological Engineering, 51, 282-286. https://doi.org/10.1016/j.ecoleng.2012.12.022

Wallace, T. C., Murray, R., \& Zelman, K. M. (2016). The nutritional value and health benefits of chickpeas and hummus. Nutrients, 8(12), 766. https://doi.org/10.3390/nu8120766

WHO (2012) The world health report. World Health Organization, Geneva. https://www.who.int/whr/previous/en

Wood, J. A., \& Grusak, M. A. (2007). Nutritional value of chickpea. Chickpea breeding and management, 101-142. https://doi: 10.1079/9781845932138.005

Yadav, J., \& Verma, J. P. (2014). Effect of seed inoculation with indigenous Rhizobium and plant growth promoting rhizobacteria on nutrients uptake and yields of chickpea (Cicer arietinum L.). European journal of soil biology, 63, 7077. https://doi.org/10.1016/j.ejsobi.2014.05.001

Zia-Ul-Haq, M., Shahid, S. A., Ahmad, S., Qayum, M., \& Rasool, N. (2012).

Mineral contents and antioxidant potential of selected legumes of Pakistan. Journal of Medicinal Plants Research,6(32), 4735-4740. https://doi.org/10.5897/JMPR12.255 